\title{
Együttműködő befogadás, kizáró hatalom
}

\author{
Az egyenlőtlenségek új modelljei a magyar társadalomban
}

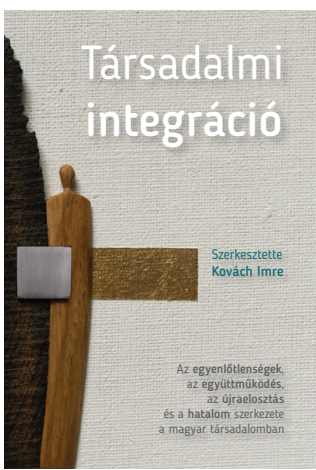

\author{
A. GERGELY ANDRÁS ${ }^{1}$
}

Valahol talán megvan kies szabványa, értékálló modellje vagy kiadói-szerkesztőségi alapmintája olyan írásoknak, melyek tanulmányként vagy kiadványok ismertetőjeként szerepelnek. Ezek persze nem sémák, mint amiképpen a szóbanforgó kötetek sem sematikusak soha. Olykor azonban kétségtelen alapélmény lesz: mintha ezt már ismerném, erről már olvastam volna, itt vagy ott már „lefutott” témakör, vagy a szerző-szerkesztő ugyanaz, s akkor mintegy kész a „tapasztalat” a megismerésről. Valamiképpen így érzem magam, mikor az utóbbi évtizedek társadalomtudományi főműveit tekinteném át, s vissza-visszaköszönnek címek, szerzői körök, tematikai univerzumok - holott épp így, éppen ezt még biztosan nem ismerhetem.

Ekképpen jártam a Kovách Imre szerkesztette Társadalmi integráció - Az egyenlőtlenségek, az együttmüködés, az újraelosztás és a hatalom szerkezete a magyar társadalomban kötettel is. ${ }^{2}$ Mintha már írtam volna egyszer róla, mintha már viszszaköszönnének a táblázatok, fejezetek témakörei, a kulcsszavak, s a szerzői kör. De mégsem. Ha közelebbről nézem, korántsem „megvolt ismeret” ez, s épp e közelről nézés „áttekintő” sémává válása téveszt meg. Ugyanis számos kutatói és érdeklődési kör kíván integrációs mechanizmusokkal foglalkozni, s bizonnyal ezek között sem utolsó Kovách Imre kutatástörténete, mely három-öt évenként (évtizedek óta) szinte vissza-visszatér a társadalmi integrációs alapkérdések kutatása, s az eredmények összegzése felé. (Egyik utóbbi, munkatársaival szerkesztett kötete, a Társadalmi integráció a jelenkori Magyarországon számos jelentős kutató hivatkozásai között szerepel a Metszetek és a socio.hu oldalain, s mintha magam is írtam volna róla.) ${ }^{3}$ A kötet ismételt említése vagy hivatkozása mégis megokolt itt annyiban, hogy

\footnotetext{
${ }^{1}$ Egyetemi tanár, ELTE TÁTK Kulturális Antropológia Tanszék.

${ }^{2}$ Belvedere Meridionale, Szeged, 2017, 378 oldal.

${ }^{3}$ Kovách I. - Dupcsik Cs. - P. Tóth T. - Takács J. (szerk.) (2012): Társadalmi integráció a jelenkori
} 


\section{RECENZIÓ}

Kovách egész szakmai életútja valahol a rétegződés kérdései, az integráció mechanizmusai, a mechanizmusok és társadalmi tagoltsági alapkérdések körül helyezkedik el, de jellegadó szerepet nyert újabb írásaiban a (talán korábban mechanikus strukturális modell névvel illethető, ma már egyre inkább) kulturális tőke, prekaritás, normák, értékrendek társadalmakat átható tónusa - mondhatnám valamely emberközelibb életkép-megjelenítés. S éppen e szempontból izgalmas a kollektív (2012-es) kötet tartalmának összehasonlító tükrözése a 2017-es integrációs/dezintegrációs témaválasztással. A korábbi, és fölöttébb hangsúlyozni kell: rendkívül impozáns szerzőgárdával, mintegy tizenöt-húsz oldalas tanulmányokból kiállított kötet önálló fejezetekbe tagolja üzenetét az értékek és bizalom, a települések és régiók, a gazdaság és munka, a befogadás és kizárás, valamint az egyének-csoportok-közösségek tematikai univerzumra építve. Vele kontrasztban a 2017-es tanulmány-válogatás integrációs mechanizmusok, rétegződés és integráció, normák és értékek, valamint kapcsolatok fejezetcímekkel kínál szerkezeti áttekintést. De kínálkozik a párhuzam (már a korábbi kötet bevezetőjében, Kovách Imre és Dupcsik Csaba szövegében) is arról: az utóbbi „ötven év társadalomtudományi irodalmában (és ennek hatására a közbeszédben) a társadalomszerkezet és az egyenlőtlenségek rendszere volt a domináns fogalmi keret, amelyben a magyar társadalomról szóló elemzések megszülettek. Ez a paradigmává vált tudományos beszédmód - annak ellenére, hogy ma is képes érvényes (rész)eredményeket termelni - az ezredfordulón 'elfáradt', és így kevésbé alkalmas a jelenkori, minden korábbinál összetettebb, gyorsabb társadalmi változások követésére.” (2012: 7) Az új elméleti „keretfeltételek” leíró megalkotására elszánt kutatói kör, mintegy a szakma egésze ebben az értelemben és minden más (módszertani, forrásfeltárási, kritikai, interpretációs, összehasonlítási, másodelemzési, empirikus, stb.) eltérések „feloldására” az átmeneti fázisban éppen az integráció kulcsfogalmába vetíthető multidiszciplináris vagy interdiszciplináris megközelítések vállalását tekinthette megoldásnak, vagyis azt, hogy a „posztmodern" társadalomkutatás újabb fogalmait, helyenként lokálisabb, máskor univerzálisabb spektrumát egy közbülső, még a vitás szerkezeti kérdések megoldása előtti problematika övezetébe terelhessék. Ekképpen a fogyasztás, az egyenlőtlenségek új rendszerei, a piaci szektorok viszonya, a szociábilis függésrendek új dimenziói is oly módon kerülhettek immár a kötet (és az azt megelőző hosszabb kutatási periódus, több intézményes partnerség kitermelte tudásanyag révén) megképződött tapasztalati anyagba, hogy azok újdonatúj rendszerré illeszthetők lehetnének talán.

Éppen e kontextusban látszik mérvadónak, ilyen perspektívából mutatkozik érvényesülni képesnek az áttekintő 2012-es kötet horizontjához képesti újjáformált kérdésfeltáró (s egy nagyobb szabású négyéves kutatási projekten alapuló) 2017-es könyv, mely önképe szerint „új szempontból tekint a társadalmi egyenlőtlenségekre.

Magyarországon. Budapest, Argumentum Kiadó - MTA Társadalomtudományi Kutatóközpont (Szociológiai Intézet), 440 oldal. 


\section{RECENZIÓ}

A kutatás eredményeként létrejött egy új egyenlőtlenség modell, amely sokkal több szempontot figyelembe vesz a korábbi, munkajellegre alapozott rétegződés modellekkel szemben, például a kapcsolatokat, a szubjektív kirekesztettséget, a civil részvételt, a munkaintenzitást, az intézményi bizalmat vagy a normaszegés elfogadását. Az új modell alkalmas az egyenlőtlenségek árnyaltabb kifejezésére, a dezintegráltság pontosabb mérésére, a középrétegek jellegzetességeinek a pontosabb leírására" (mint ezt a kötet ismertető szövege jelzi). Kovách Imre mint projektvezető és a kötet szerkesztője az „Integrációs és dezintegrációs folyamatok a mai magyar társadalomban" kutatási tematika irányítója is, tehát fajsúlyos akadémiai program meghatározó irányváltását készíthette elő, amikor nevet, jelentőséget adott a vizsgálat egészén belüli új utak keresésének, melyek fóirányában a jelenkori magyar társadalom tagolódása és az egyenlőtlenségeket alakító folyamatok megismerési lehetősége kerülhetett közelebb szemléleti alapvetésként. Itt két momentum hangsúlyára érdemes a figyelmet fókuszálni.

Egyfelől arra, hogy bár Kovách eredendő kutatási aspektusa a hajdani rétegződés-modellek megalkotási idejéhez (1980-as évek) képest markánsan gyarapodott a vidék- és településszociológia sokféle tematikájával, idővel már maga is megállapítja, hogy a kulcs-problémák a kortárs empirikus vizsgálatok tükrében a modellek egzakt ismertetésén túl a társadalom politikai integrációjának elemzése felé tértek el, „ami eddig teljesen elhanyagolt terület volt”, s ezt gazdagítja immár „a jóléti és projektalapú redisztribúció” részletes, „,úttörőnek számító” leírása, továbbá „a társadalmi tőke, a területiség és integráció összefüggéseinek leírása, a rétegződés, a normák, a fogyasztás és integráció összefüggéseinek az elemzése, illetve a kapcsolatok integratív szerepének az elemzése". A sokrétű és átfogó igényű ráközelítés ezúttal az értéknormák, kapcsolatok és lakóhelyiség dimenzióival is gazdagodik! Ez pedig fontos lépés, éppenséggel nem az integrációs problematikák ellenében, hanem irányában!

Másfelől - jóllehet volna még több „felől” és „felé” momentum is - érdemi hangsúlyt kap a kutatási-szerkesztési-megértetési szempontok között a rétegződés és változás, a társadalmi beilleszkedettség és viselkedésmodellek szerinti át- vagy újratagolódás szempontja is. A kérdésről a kötet kifelé tükrözött képe szerint „a politikai viselkedést és értékorientációt nem lehet megérteni az egyének réteghelyzetéből, strukturális pozíciójából kiindulva. Nem a társadalom szerkezete és állapota határozza meg a politikát, hanem sokkal inkább a politika integrálja a társadalmat" - szól a kardinális meglátás. Ez pedig részint megerősíti az előző bekezdés tónusában már megjelenő aspektust, részint meg pontosítja, tónust ad neki, aláhúzza jelentőségét. Alább érzékenyítő aspektussal körvonalazom ezt, de ehhez rövid személyes vallomásra kell két mondatot szánjak.

Nem két mondat, hanem két konkrét esettanulmány és számos, alaposan és részletesen citált szakirodalmi forrásutalás is kevés volna annak „bevallásához”, hogy miképpen és mióta fogalmazok „magáncélra” kifejezetten a pártállami idők „enge- 


\section{RECENZIÓ}

délyezett”, „megtűrt” rétegződéselméleti kutatásaival szembeni szakmai véleményt. Ezekből a nagyvolumenű, soktáblás, sokábrás, sokdecilises kutakodásokból nekem a nyolcvanas évek közepe óta durván és keményen hiányzik maga a létező Ember, a válaszadó egyén, a kapcsolathálói közt vergődő személyiség személyessége és hiteles kétkedése az egyedileg általa kiváltképpen befolyásolhatatlannak tűnő társadalomkép megalkotása és megalkotói (a „szociomókusok”) ellenében. Nem kellő szakmai fölvértezettségem okán, s mert amúgy egyénként és kutatóként egyaránt azt vélem érvényesnek, lehessenek sokfélék a vélemények, a kifejezettek, a rejtettek, a leíróak, a személyesek, az intézményesek és így a kutatóiak is, ennek roppant ritkán adtam hangot nyílt szakmai vita és virtuális „győzelem” tónusában. Kovách Imre több rendszerváltás utáni kötetéről nemcsak ismertetőket írtam, s nem csupán kollégájuk voltam több évig, de épp az általa kialakított fiatal kutató team egyre izgalmasabb és egyre mélyebb szakmai érdeklődésének kialakulásában látom Kovách indokolhatóbb eredményességét, mintsem további derivátumok és táblázatok tartományaiban. Úgy vélem tehát (az itt bevallott perspektíva-torzulás mellett, sőt ennek ellenében is), hogy ami a struktúra-specifikus leíró modellalkotásban éppen az utóbbi másfél-két évtizedben nóvumként jeleníthető meg, az valójában lehetett a fókuszváltás, a horizont-tágulás mögöttes oka is, ugyanis ami egykor a társadalmi „struktúra-orientált" szervezeti adatok látószögében mindenkor prioritást kellett kapjon, szükségképpen egészült ki a nemcsak szervezet-specifikus, hanem éppen az érték-orientált, gyakorlat-orientált, (idővel persze a haszon-orientált, piac-orientált, gyakorlat-orientált, kommunikatív szférákat átható) másféle mikromodellek társadalmi tényeivel és normatív rendszereivel, s nem utolsósorban a Papp Zsolt közvetítette, Habermas kidolgozta „adaptációs stratégiák” másik kulcsfogalmával, a kultúra-orientált aspektussal. Úgy látom, ezért úgy fogalmazom tehát, hogy a Max Weber-i értékmentesség követelményével a nyolcvanas években még „objektiválható” tudást legitimáló hazai struktúravizsgálatok (talán éppen a rendszerváltás során kibontakozni kezdő) kapitalizmus és polgári demokratikus tervszabályozási átalakítás következtében mintha igényt formálna immár arra, hogy a virtuálisan megképződött új társadalmi struktúra és integrációs modell ellenoldalán végre elkezdje észrevenni a térbeli tagoltság szabta másságokat, a polgári világ formális-ideológiai-értékrendi egyenlőségteremtő szabályozottságának hátterében meghúzódó esélyegyenlőtlenségi versenyhelyzeteket, a gazdasági kihívásokból fakadó leszakadást és anómiát, munkamigrációt és újraelosztási érdekversenyt, a politikai integráció mögötteseként a politikai érdekcsoportok értékcsoportokká válását, a rétegződésben a szegmentációt és a végletes-tömeges-korosztályi-területi leszakadások gyarapodó tömegét, a normák és értékek integrációs problematikái között a közhasznúság és esélykülönbségek elleni autonóm kezdeményezések létét és hálózatait, a kapcsolatkutatásokban a társadalmi szerepek, mentális örökségek, térségi függésrendek gazdag adatanyagát is, melyek a „társadalmi integráció" részeként képesek megfogalmazni a rászorultság, a 


\section{RECENZIÓ}

közhasznúság, a leszakadás, a szolidaritás, avagy másképp megnevezve a korábbi struktúrát felülíró stratégiák meglétét, ezek sokasodását és adaptációs modellekké erősödését, vagyis a tágabb értelemben vett kultúra-orientált modellek egyre figyelemfelhívóbb rendszerének megnyilvánulásait (vagy ezek reprezentálódását és mérhetővé válását, beleértve a módszertani nóvumok kiteljesedési esélyeit is).

$\mathrm{Az}$ itt futtamban elősorolt új aspektusok tehát alapjaikban is tükrözik a Kovách-életműhöz és tematikákhoz viszonyulásom változását, az oeuvre bizonyos tónusainak változását (innovációját) is, továbbá a két kötet közötti nemcsak időbeli, de kutatási horizontok kereszteződését vagy (párhuzamossá válását tekintve) közeledését is jelzik, s erre akár ráfüzhető is lenne a tartalomjegyzékből kivilágló „funkcióváltozási” vagy funkció-orientált kereső modell megannyi árulkodó eleme is. A 2017-es kötet Kovách Imre által írt fogalmi és megközelítési bevezetője, valamint a Kovách Imre - Hajdu Gábor - Gerő Márton - Kristóf Luca - Szabó Andrea értelmezésében megmutatott integrációs modell (7-48. old.) mintegy ráhangol az újraelosztás (Czibere Ibolya - Gerő Márton - Kovách Imre), a politikai integráció és az érdekcsoportok (Gerő Márton - Szabó Andrea), a társadalmi tőke integráló hatásainak kérdései (Hajdu Gábor - Megyesi Boldizsár), továbbá mindezek területiséggel összefüggő dimenziói (Csurgó Bernadett - Csizmady Adrienne - Kovách Imre) közötti „mechanizmusok” megnevezhetőségére (51-213. old.). Ezekre következően a státuszcsoportok és az egyenlőtlenségek elméleti küzdelmében korábban kiegyezést nem lelő aspektusokat mint „paradigmaváltás igényét” megfogalmazó előmunkálatok kiteljesedő példatárát hivatkozza Kovách a fogalmi bevezetőben, $\mathrm{s}$ az „integráció és integrációs mechanizmus fogalmának értelmezéseit" bemutató rendszerező táblázatában (7-11. old.), de az alapozó kvalitatív modellkísérletek esélyeire is utal, hogy erre megerősítésként a fogyasztással, normákkal, értékekkel és segítési hajlandósággal pontosítható fejezetben (217-229. old.) vissza is térhessen, amire ezután Kovách Imre - Kristóf Luca - Szabó Andrea és Huszár Ákos - Sik Endre résztémái következnek megerősítésként a rétegződés-mérés további perspektíváival, hogy azután a fogyasztással, normákkal, értékekkel és segítési hajlandósággal pontosítható fejezetben Kristóf Luca - Szabó Andrea, valamint Koltai Júlia - Kristóf Luca - Simonovits Bori a Bourdieu-féle tőketípusok és a Kolosi-féle státuscsoportok ellenpontjaként az életstílus, életmodell, magaskultúra-fogyasztás, munkaerőpiaci integráltság empirikus anyagával igazolhassa egy újszerű kérdésfelvetés-komplexum kérdőíves megismerési lehetőségeit (267-304. old.). A záró blokk a kapcsolatoké, a hálózati tipológiáé, naplók és kötődések „egocentrikus” viszonyrendszerének kutatásáé, meg a lakóhelyé, ahol a társas kapcsolatok ugyancsak kitettek a régiók dezintegrációs, gyenge kötésekkel a társ-hiányt leíró dunántúli, közép- és keletmagyarországi szegénységi környezeté, s ebben Albert Fruzsina - Dávid Beáta - Gerő Márton - Hajdu Gábor, továbbá Dávid Beáta - Lukács Ágnes - Huszti Éva - Barna Ildikó, illetve Koltai Júlia - Nemes Dóra szerzőcsapatok részletező tanulmányaié (307-75. old.), akik 


\section{RECENZIÓ}

révén mintegy térképzetként is láthatóvá válik, miként rejlik az integráció/dezintegráció függő mutatója is a községi, szegénységi, térségi beilleszkedettség eltérő modelljeiben, függő relációkban, innovációs kapcsolati potenciálokban vagy ezek hiányában, valamiféle bekebelezésben és kiszorításban egyaránt.

Épp a fenti érdeklődési „trendváltozás” okán a legkevésbé sem lenne érdemes, a továbbiak és részletek alapján még ennél is kevésbé volna illedelmes valamiféle „olvasati szentenciába” fordítani a tanulságos áttekintések módszer és interpretációk alapján is eltérő tételeit. Ám talán bizonyosságot lelhetünk ama kihívásban, amit Kovách Imre és munkatársai (mondjuk egy klasszikusabb paradigma alapján) a habermasi „rendszer” és „életvilág” ontológiai különbségei közötti összhang kutatásával, a strukturális kérdések funkcionális lenyomatainak állapotrajzával mégiscsak megneveztek. Ami ezekből is harsányan kikiált, az a demokratikus átmenet révén megerősödött modell-értékek málladozásának tapasztalata egyfelől, a cselekvéselméleti ésszerűség és az instrumentális/kommunikatív racionalitás klasszikus perspektívái révén másik oldalról, melyek már talán széleskörűen ismerősek is mint deskriptív metódus részei. Látható, hogy az integrációs esélyek (elvileg magasabb, „makro-szintü”) modellizálhatósága csak részben múlik a politikai, pártszerű, társadalmi rétegszerkezetre emlékeztető mikro-univerzumokon, mert mindezeket is egyre láthatóbban működtetni képesek és hajlamosak a nem-formális érintkezési utak, magánéleti pályák, nyilvánossági relációk meghatározó komponensei. Ennyiben a társadalmi integráció magában rejt valamely szocializációs és kulturális értékrendet is, sőt, mintegy „klasszikusan” is valamely erkölcsi-politikai célok (demokratikus feltételek melletti) képzetét, kialkudásának igényét vagy esélyét is lehetségessé teheti. Ugyanakkor, mert a társadalom bázisait, materiális újratermelését elvégző makro-rendszer szervesen is kapcsolódhat/kapcsolódik az életvilág belső racionalitásával, ez mintegy előjön, megjelenik akár a térségi, akár a civil szerveződési, autonóm, nem-intézményes rendszer-követelmények jogi és morálisan-mentálisan lehetséges szféráiban is, ahol a rétegződési komponensekhez tapadó technikai-technológiai modernizációk bár látványos területi különbségekkel, valahol messze távol mégis megokolt elvárásként, innovatív esélyként, a közösségi életvilágok szintjein már az emberi csoportok horizontján is lehetséges perspektívákként megjelenhetnek. Ennek hol része, hol szerves tartozéka, hol következménye vagy késői járuléka a közösségi anómiák jelenléte, az életvilág gyarmatosítása, a kiszolgáltatottság minőségének árnyaltabb, de intenzívebb működtetése, amire az integráló rendszer tartós múködésének feltételezésével már számítani is lehet. Vagyis: a változás a struktúrában még nem változtat a kultúrában, $\mathrm{s}$ a társas vagy társadalmi kiszolgáltatottság sem okvetlenül módosít az integrációs modelleken, hanem rejtett lehetőségként ott marad magában a rendszerben a közösségi szintű szabadságfeltételek lehetséges igénye, továbbá a rendszer intézményei (nemzetgazdaság, párt-államhatalom, totalizált közigazgatás, civil jogérzékenység, mozgalom-szintű társas elégedetlenség) 


\section{RECENZIÓ}

szféráiban valahol ott marad a hiábavaló stratégiai és bürokratikus sikerképesség morális deficitje, az igazságosság mindenkori érzületének rejtekező minimuma, valamint a kialakult érdekkonfliktusok tompítására alkalmas ellenoldali mechanizmusok számos célrendszere, értékképzete. Ezek ugyan a struktúraformáló folyamatok terén talán kevéssé számszerűsíthetők, ám a szolidaritás, az egyeztethető érdekek vagy megjeleníthető értékek terén mégis társas interakciókban kereshetnek önmegjelenítési utat. S ez út, ilyen utak, az integráció további esélyeinek efféle mechanizmusai azok, amelyeknek változó alaptónusa, a széttagolódás és dezintegrálódás kíméletlenné válása volt a 2012-es kötetnek is alaphangja, így hát annyira nagy tévedésben mégsem voltam a két mű közelségét illetően - de kétségtelen, hogy az öt esztendővel későbbi tanulmány-válogatás az integrációs folyamatok kevesebb, ám mélyebb zavaraira, viszont a kulturális folyamatok zavaró leépülésére, kínos válságtüneti jellé válására hangoltságot mutat immár.

S lehet persze, hogy a morális, transzcendentális vagy kevésbé struktúraalkotó kölcsönhatások nem mérhetők ugyanúgy, mint a rétegképző vagy integráltsági mutatókkal ékesíthető társadalmi tények - ám ezek jelenlétét talán már az efféle újabb integrációs kutatások is méltóképpen tükrözhetik (lehessen talán itt utalni a kötetben az érdekek integrációs mutatóira Gerő Márton aspektusai között, a szegmentáció és prekariátus jellegadó jegyeire Sik Endre megfigyeléseiben, az újraelosztás tudástőke vagy értékmodellek vonzásköre szempontjából fontos momentumaiban Czibere Ibolya adatai szerint, a fogyasztás értékrendi normáinak esetében Kristóf Luca és Simonovics Bori témakörében, vagy a „kapcsolati naplózás” jelzéstára szempontjából fontos komponensek esetében Dávid Beáta, Barna Ildikó és munkatársaik munkáiban).

Mindezek nyomán, zárásképpen utalni érdemes az emberi viszonyok jellemző racionalitásai, az életvilág komponensei közötti érték-orientációk eltérései, és a rendszerszintű strukturális függésrendek egyenlőtlenségi modelleket kínáló magyarázatai közötti értelmezési különbségek, a mediatizált függésrendek és újraelosztásra kerülő tőketulajdonok (pénz, tudás, térbeli tagoltság, mobilitások, hozott készségek, befogadási érzékenységek, stb.) változásai közepette megmutatkozó tünetekre: a hatalom kizáró, elkülönítő médiumától elszenvedett kiszolgáltatottság (kizárás) bürokratikus mechanizmusait is egyre inkább érdemes figyelembe venni a társadalmi eligazodás, célok, értékrendek akut változásai sorában, az integrációs jel-együttes, tünetek és következményeik terén. Ehhez, s a szakmai kutatási horizonton az új modellek lehetőségeihez, leképezési irányaihoz járul hozzá Kovách Imre és munkatársainak újabb kötete. 
www. metszetek.unideb.hu

\section{RECENZIÓ}

\section{Irodalom}

Kovách I. (szerk.) (2017): Társadalmi integráció - Az egyenlőtlenségek, az együttműködés, az újraelosztás és a hatalom szerkezete a magyar társadalomban. Budapest - Szeged, MTA TTK Szociológiai Intézet - Belvedere Meridionale.

Kovách I. - Dupcsik Cs. - P. Tóth T. - Takács J. (szerk.) (2012): Társadalmi integráció a jelenkori Magyarországon. Budapest, Argumentum Kiadó - MTA Társadalomtudományi Kutatóközpont Szociológiai Intézet. 